\title{
Vergi mevzuatında işçinin durumu ${ }^{[*]}$
}

\author{
Sait Kandan \\ Çalışma Bakanlığı Mïfettişlerinden
}

Vergi mevzuah karşısında işçinin durumu geniş bir surette sosyal politikaya bağlıdır. Filhakika muhtelif zamanlarda işçileri ilgilendiren vergiler, o zaman ve o memlekette görülen sosyal politikanın tesiri altında vazedilmiş veya tadil edilmiştir.

Vergi, biliyorsunuz ki hükûmetin masraflarına yani umumî ihtiyaçların tatmini için yapılan masraflara vatandaşların iştirak hissesidir. Gaston Jèze vergiyi ( umumî menfaatlerin masrafların kapatmak için sabit kaidelere tevfikan fertlerden teşkilâtlanmıs siyasî bir toplulư̆un üyeleri olmak sıfatiyle istenilen nakdî bir kıymettir) şeklinde tarif ediyor. Bence bu tarifin en mühim kıymeti vergiyi bir servis karşılığı ödenen bir para değil, sosyal bir mükellefiyet olarak nazara almasıdır. Filhakika fiilen de vaziyet böyledir. Sosyal bir mükellefiyet olan verginin sosyal politikaya ne kadar bağlı olduğunu istihlâk vergilerinin tarihi gösterir. Istihlâk vergilerinin iktidardan değil, istihlâktan ve hattâ verimli olması bakımından en mübrem ve umumî istihlâklardan alındığı, binaenaleyh impopulaire $=$ halkçı olmyan bir vergi olduğu malûmdur. Bu vergiyi fakir halk, zenginlere nazaran daha çok aŏır bir şekilde öder. Bugünün telâkkisi budur. Halbuki 17 inci asırda malikler sınıfının siyasî iktidara sahip ve hakim bulunduğu devirde bu vergiler. maliye sistemlerinde geniş bir mevki almış ve müdafaa edilmiştir. Çalışan sınıfı daha mütevazi yaşamağa alıştırır, daha fazla çalışmağa sevkeyler denilmiştir. İstihsal artar ve maliyet fiatı düşer. Bugün malik olmıyanlar sınıfının haiz olduğu kudret dolayısiyle istihlâk vergilerini bu şekilde müdafaaya imkân yoktur.

Imdi, sosyal politika nedir? Sosyal politikayı diğger arkadaşlarım, benden evvel izah ettiler. Sosyal politikayı, sosyal sinifların hareketleri, tezatları ve mücadeleleri karşısında Devlet ve Hu-

[ ${ }^{*}$ ] Bu konferans $5940^{\circ}-46$ ders yıl içinde fakültemizde verilmiştir. 
kuk nizamını ayakta tutmağa ve idame etmeğe matuf bir siyaset şeklinde yapılan tarif, cemiyet dahilinde sinıfları ve bu sınfflar arasında mücadeleyi mütalâa eden bir tariftir.

Sosyal politika, sınıf tezat ve mücadelelerini kabul etmeksizin de fertlerden hiçbirinin cemiyet dahilinde muayyen bir yaşama seviyesinden aşă̆ı düşmemesini gaye ittihaz eden ve fertlerden herhangi birinin sefaletinden bütün cemiyeti sorumlu tutan bir politika olarak solidarist bir görüşle tarif olunabilir.

Sosyal politikanın bir memleketin maliye sisteminde ve daha dar manasiyle vergi sistemindeki tesiri her zaman mevcut olmakla beraber zaman zaman cihet deł̧iştirmiştir. Fakat her zaman vergi adaleti prensibi ileri sürülmüştür. Adalet fikri. mutlak bir kıymetı haiz dȩ̧ildir, her millet, her nesil, her fert için adalet fikri ayrıdır. Adalet fikri malikler sınıfı ile hiçbir şeye malik olmıanlar sınıfı için ayrı ayrıdır. Binaenaleyh vergide adalet fakirler ve zenginler için ayni değildir. Vergide adalet fikri, milletlerin hayatında büyük tesirler husule getiren bir idealdir. Bu ideal için inkılâplar yapılmıştır. Şimdi de her tarafta vergide daha çok adalet temini içindir ki malî ıslahat yapılmakta veya talep edilmektedir: Her içtimaî sınıf, vergide sosyal adaleti kendisine en faydalı olacak vergi sisteminde bulur. 19 uncu asrın sonuna kadar malikler sınıfı siyasî iktidara elkoymuş bulunmaları dolayısiyle bu kudretlerinden istifade etmişlerdir ve malî sisteme kendi sosyal sınflarına çok müsait bir renk vermiştir. Ingiliz ve Fransa liberálleri yalnız verginin randumanı, verimini düşünmüşlerdir. Sosyal gayeleri nazarı itibare almışlardır. Bugün siyasî kudret el deł̧iştirmek yolundadır. Adetçe, kemmiyetçe daha çok olanlara malik olmıyanlar sınıfına geçmektedir. Binaenaleyh sosyal unsur, yeni muktesit ve maliyecilerde çok büyük bir ehemmiyet almıştır.

Ingiliz Snovden'in dediği gibi verginin zenginlerden serveti alıp fakirlere dağıtmak gibi bir gayesi olduğu hakkındaki sosyalist ve komünist ekollerin müfrit nazariyelerini bir tarafa burakırsak sosyal gaye endişeleri gittikçe nazariyelerde yer almakta ve hükûmet adamlarına rehber olmaktadır. Seligman'ın dediği gibi devlete malî menabî temini gayesiyle bile olsa camianın menfaatine fertlerin gelirleri üzerinden bir azalmaya sebep olması itibariyle vergilerin içtimaî tesir ve neticeleri vardır. 19 uncu asırda sanayi hayatının inkişafı neticesinde köylerden şehirlere olan akın, Ürbanizm cereyanı neticesinde şehirlerde büyük isçi kütleleri 
teşekkül etmiştir. Evvelâ yeni iktisadî hayat ve ekonomik şartlar sosyal hayat ve şartları tesbit eden mühim faktörler olarak manzur olmuștur. Sonra sosyal hayat ve şartlar ekonomik ve malî duruma tesir etmiştir denilebilir. 19 uncu asron birinci yarısında Liberal ekolün surf vergiden randuman ve verimi esas olan nazariyeleri hakim olmuștur. 19 uncu asrın ikinci yarısında sosyal politika fikirleri gittikçe büyük bir önem kazanmağa başlamıştır. 19 uncu asrın sonlarında 20 inci asrın başlarındadır ki Alman kürsü sosyalistlerinin nazariyeleri ehemmiyetli bir şekilde dünyaya yayılmıştır. Bugünkü malì sistemlerin menşeini bu nazariyelerde aramak lâzımdır.

1914 - 1918 harbi maliye ilminde sosyal görüşün ehemmiyetini artırmışrır. Sermaye üzerinden vergi ahnması suretiyle harp yükünün likidasyonu tavsiye olundu. Birçok sermayedarlar, devlet tahvili almışlar, faiziyle geçiniyorlar, bu faizi de harple fakirleşmiş sınıfların, meselâ işçilerin fedakârlı̆̆ı ile temin olunuyor, şu halde sermayeyi teklif etmek lâzımdır, deniliyordu. Bugün sosyal politikayı maliye ve vergi mevzuunda muhtelif manalarda anlamak lâzımdır. Evvelâ komünist tandansh też vardır. Buna göre idare edenler, maliye müesseseleriyle fertler arasında servet müsavatı tesis etmek mecburiyetindedir. Wagner ve Snovden bu tezin sâlikleridir. Saniyen tamamen sosyal tez vardır. Buna göre maliye müesseselerinin gayesi fertler arasinda müsavat temin etmek değildir. Bununla beraber vergi sistemlerinin kurulmasında sosyal gayeler gözetilmelidir. Gaston Jéze'in Seligman'ın tezleri budur. Sosyal politikayı solidarist bir görüşle izah da mümkündür. Biz bu sonuncu tezi terviç ediyoruz.

Komünist tandanslı teze 15 inci asırda Gui - cciardini de rastlıyoruz. Bu müellif : hepimiz ayn devletin müsavi fertleriyiz, vergi bizi aynı iktisadî seviyede birleştirmezse adalet ve müsavat olamaz, diyor. Modern müellifler arasında bu solcu tezi ençok izah eden Wagner'dir, Wagner'e göre tamamiyle malî olan görüs yanında, sosyal görüs vardır. Bunun açık olan gayesi şudur: Bugün mülkiyetin iktisap suretleri ve serbest rekabet sistemleri üzerine müesses bir gelir tevzii vardır. Bu haksızdır. Vergi sistemi vasitasiyle bu gelir tevziinden farklı ve daha âdil bir millî gelir tevziini temin etmek lâzıındır. Devlet, malî görüşe olduơ̆u kadar sosyal politika görüşüne de intibak etmek mecburiyetindedir. Efrattan, hususî iktisattan büyük kâr menbalarını kaldır- 
malı, yeni bir reji kaidesiyle bunları Devlete devretmelidir. Bu suretle aşağı sınıflara hususî bedeller temin olunabilecektir.

Maliye ilmindeki sosyal noktai nazarın ehemmiyetini işaret etmekle beraber Seligman, Wagner'in fikrinde deł̧ildir. Seligman'a göre vergide malî gayenin yalnız Devlete menâbi teminini, sosyal gayenin ise sosyal münasebetlerde arzuya şayan bir dĕ̛̛işiklik vücuda getirmeyi gaye ittihaz ettił̆i hakkındaki mütalâa varit deł̆gildir. Zira vergi Devlete menâbi teminini gaye de ittihaz etse mühim içtimaî neticeler hasıl eder. Maliye ilmi, sosyal bir ilimdir.

Adalet, şunu icabettirir ki Devlet elinde her iki kefesi müsavi bir terazi tutmalıdır. Âdil olmıyan hiçbir avantaj vermemelidir. Herkese Kanun nazannda ayni haklar verilmelidir. Devlet, bilerek servetler arasındaki adaletsizlikleri; arttırmamalıdır. Ama, bu adaletsizlikleri ortadan kaldırmağa çalışmamalıdır. Sosyal bir reform zaruridir. Ancak bu reform imkânını kanun vazı tarafından sınaî ve içtimaî meselelerde alınacak hareket tarzında aramak lâzımdır.

Hülâsa, şimdi asri vergi sistemlerini sosyal politika geniş bir surette idare etmektedir. Ayırım $=$ Discrimination prensibi, $\mathrm{Mü}$ terakkilik = Progression, vergide şahsiyet prensibi = La personnalité dans l'impôt, bütün asri vergi sistemlerinde yer bulan prensiplerdir. Ellerinin emeģiyle ve bir sureti umumiyede emeğiyle geçinenlerin gelirlerindeki diğer gelirlere nazaran bünye farkı uzun tetkiklere yol açmış, bütün maliye sistemlerinde nazarı itibara alınmıştır. Bilhassa iş̧̧ilerin umumiyetle ve ekonomide Tunç Kanunu adını alan tabî kanun neticesinde ücretlerinin ancak kendilerinin ve ailelerinin en zarurî masraflarına tekabül edecek en aşağı miktarda taayyün etmesi bunların himayelerini zarurî kılmıştır. Acaba çok ileriye giderek iş̧̧ilerin gelirlerini tamamiyle vergiden muaf tutmak mümkün müdür ? Bu doğru dȩ̌gildir. Zira vergi bir vatandaşlık ve şeref borcudur. 1793 Fransız Anayasasının 101 inci maddesi Devlet masraflarına iştirakin şerefli bir yük olduğunu ve hiçbir vatandaşın müstesna tutulmadığinı zikretmektedir. Binaenaleyh bu dogru değildir.

Ayırım prensibi :

Ancak çalıșma ve iş gelirlerinin zaif bünyelerinin vergi tarhında nazarı itibara alınması suretiyle ayırım $=$ Discrimination 
prensibi ileriye sürülmüştür. Bu prensip bütün asri vergi sistenlerinde tatbik olunmaktadir. Filhakika 1907 senesinden beri titaiya'da, 1925 senesinden beri Almanya ve daha sonra Amerika, Belçika, Hollanda ve bütün Balkan memleketlerinde ayırım prensibinin tamamiyle tatbiki için mükemmel ahkâm vazolunmuştur. $\mathrm{Bu}$ prensibe göre vergiye tâbi olacak gelirleri menşelerine ve karakterlerine göre ayırmak ve farklı nisbetlere tâbi tutmak làzımdır. Umumiyetle sermaye gelirleri, sermaye ile çalışmanın izdivacından hasıl olan gelirler, ve sırf çalışmaya istinat eden gelirler tatbik edilecek nisbet bakımından ayrılmaktadır. Fithakika sermaye gelirleri, evvelâ çalışmadan kazanılır, sonra sağlamdır, emindir. Sayın hocam Fadıl Pelin'in dediơi gibi esham ve tahvilât veya mevduat sahipleri vadenin hulûlunda gider, paralarını alırlar, o kadar da rahattır, bir nevi işsizlik:= oisivetéde tahassul ettiği muhakkaktır. Halbuki tamamiyle işten, çalışmadan gelen gelirlerde ihtiyarlık için ayrılan bir tasarruf hissesi vardır. Işten çıkma, hastalık vesair ihtiyaçlar karşısında iş ve emeğiyle geçinenler, çok naçar vaziyette kalırlar, gelirleri müstakar, emin değildir. Âdeta günü gününe yaşarłar. Bir tarafta bir tasarruf olmazsa işten çıkan bir işçi açtır. Ona tasarruf imkânını temin etmek, bunun için de normal ïcretine nazaran hakikî ücretinin mümkün mertebe azalmamasını sağlamak lâzımdır. Wagner'e göre bütën şartlar müsavi olmak üzere gelirler için ayni miktar bir kıymet farkh bir iktisadî kudreti temsil eder. Bu iktisadî kudret çalışma faktörünün hakimiyeti derecesinde nisbî olmakłan da daha hızla tenezzül eder. Emeŏi ile geçinenler için vasıtaiı vergilerden kaçınmak imkânı da havaici zaruriyede İkame Kanunu'nun cereyan edememesi dolayısiyle çok azdir. Su halde yainız çalışmadan husule gelen gelirlerden, sermaye gelirlerine nażaran daha çok az, nisbette vergi almak icabeder.

Fransa'da diğer büıün iratlar \%16 nisbete tâbi olduklar halde, emeğgiyle geçinenlerin gelirleri $\% 8$ nisbete tâbidir. Ikinci Cihan Harbinde bütün gelirlerde olduğu gibi 12/12/1938 tarihli Decret - loi ile yalnız \% 2 millî vergi zammı yapılmıştır. Ingittere'de 1907 senesinden beri gelirler kazanılmıs ve kazanılmamıs geiirler olmak üzere ikiye ayrılmış ve farklı nisbetlere tâbi tutulmuştur. Italya'da sermaye iratları $\% 20$, sermaye ve emek memzucu gelirle $\% 14$, serbest meslek erbabı $\% 12$, işciler $\% 9$ Devlet memurları $\% 8$ nisbete tâbi tutulmuştur. 
Bu arada, Devlet memuriarına bizden başka yalnız İtalya'da farklı ve az nisbet tatbik edildið̆ini, memurların dið̆er emeð̧iyle geçinenlere nazaran bu bakımdan farkı olmadı̆̆ından bizim doğru bulmadığımızı arzedelim.

Bizde 2395 sayılı Kazanç Vergisi Kanunu'na göre âmme hizmeti memur ve müstahdemleriyle hususî hakikî ve hükmî şahislar yanında çalışanlar ayrılmıştır. Hususî eşhas yanında çalışanlar ve işçilere (100) liraya kadar $\% 7$ ve 100 liradan yukarısı için \% 9 nisbet tatbik olunur. Devlet memur ve müstahdemleri için nisbetler daha düşüktür. Yüz liraya kadar $\% 5$, iki yüz liraya kadar "; 6 üçyüz liraya kadar $\% 7$, dörtyüz liraya kadar $\% 8$ ve daha yukarısı için $\% 9$ dur. Yukarıda arzettiğimiz gibi farkh muamele doğru değildir. Ancak biliyorsunuz ki emeğiyle geçinenlerin kazanç vergilerine, iktisadî buhran, muvazene ve hava kuvvetlerine yardım vergileri, nisbetier, muafiyetler vesair hükümlerde tam bir karşılık hasıl edecek şekilde ilâve olunmuş ve bu nisbetler çok yükselmiştir. Pahalılık zammı ve muafiyetler nazara alınmak şartiyle;

\begin{tabular}{clcc} 
Hususî ücrette & & Massiarda & Liraya kadar \\
\cline { 1 - 1 } 21,5 & & 10,5 & 50 \\
24 & 19 & 100 \\
28 & 23,5 & 200 \\
28,5 & 24 & 300 \\
30 & 26,5 & 500 dir.
\end{tabular}

Kanaatimizce bu şekilde emeł̧i ile geçinenler aleyhine, bir vergi muzâaflı̆̆ı da hasıl olmuştur. Filhakika bizde işçiler ve emeği ile geçinenlerin tâbi oldư̛̆u vergi sisteminde aynı ferdin aynı gelir için müteaddit defalar vergiye tâbi tutulması vardır. Bu, vergi muzaaflığıdır. Ve vergide yeknesaklık kaidesine de muhaliftir. Yeni hazırlanan gelir vergisi tasarısında bu gayri tabiîlik izale edilmekte ve: Diger gelirlere nazaran mukayese olunursa memleketimizde ayırım = discrimination kaidesinin tam tersinin tatbik edildił̧ görülür. Tabir caizse bir discrimination à rebours = tersine ayırım, kaidesi caridir. Yalnız son zamlar müvazeneyi biraz düzeltmiştir. Sermaye gelirleri nişbeti pek hafiftir. Asıl şayanı dikkati sermaye gelirlerinden mühim bir kısmı vergiden hariç tutulmuştur. Menkul kıymetler, mevduat, alacaklar, vergiye 
tâbi dẹ̛ildir. Çahışma ve el emeğiyle geçinenlerin vergi nisbetleri en ağırdır.

\begin{tabular}{|c|c|c|c|c|c|c|c|c|}
\hline $\begin{array}{c}\text { Ueret } v . \\
\text { fazhlids } \\
\text { " }\end{array}$ & $\begin{array}{c}\text { Ticari } \\
\text { kazane v } \\
\text { ": }\end{array}$ & $\begin{array}{c}\text { Hususî̀ } \\
\text { üeret v. } \\
\% \%\end{array}$ & & & & & & \\
\hline$\overline{7}$ & 14,5 & 21,5 & ayda & 50 & liradan & senede & 600 & lira \\
\hline 9,5 & 14,5 & 24 & $\checkmark$ & 100 & * & 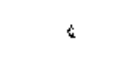 & 1200 & : \\
\hline 13,5 & 14,5 & 28 & $z$ & 200 & \& & : & 2400 & $\varepsilon$ \\
\hline 14 & 14,5 & 28,5 & 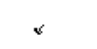 & 300 & 4 & 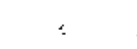 & 3600 & * \\
\hline 15 & 15 & 30 & * & 509 & $c$ & . & 6000 & $*$ \\
\hline 15 & 16 & 31 & 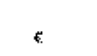 & 600 & 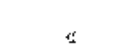 & $*$ & 7200 & $*$ \\
\hline 17 & 17,5 & 34,5 & $\therefore 1$ & 1000 & 2 & 。 & 12000 & $\therefore$ \\
\hline
\end{tabular}

Yani son vergi zamları yapılana kadar bilfarz 3600 lira kazanç üzerinden bir müstahdem 1026 lira ödemekte iken aynı kazancı olan bir tacir yalnz 522 lira ödemektedir. Bu suretle memleketimizde ticarî kazanca nazaran safî gelir üzerinden iş̧̧iler bir misli fazla vergi vermektedir. Yeni hazırlanan gelir vergisi tasarısının ayırım bakımından hükümlerini biz, kâfi bulmamaktayız. Filhakika ayırım bakımından sedüler vergilerin kabulü en muvafık olurdu kanaatindeyiz. Alman vergi mevzuatı gözönünde tutularak kaleme alınan bu umumî gelir vergisi tasarısına nazaran ayırım vasıtalı bir şekilde yapılmak istenilmektedir. İş̧̧iler ve umumiyetle emeğiyle geçinenler yalnız gelir vergisine tâbidirler. Ticaret erbabı ayrıca bazı karinelere müstenit işletme vergisi vermektedirler. Ancak bu sistemin alındığı Almanya'da bile umumî gelir vergisinde emeğiyle geçinenler ayn muameleye tâbi olduklan halde gelir vergisi kanun tasarısında gelir vergisi nisbetleri bakımından iş̧̧iler ve ticaret erbabı kazançları arasında hiçbir fark gözetilmemiştir. Bu şekilde tam bir ayırım yapılmasına imkân yoktur. Vazıh, kat'î ve kâfi derecede bir ayırım yapılması mümkün değildir. Esnaf ise aksi bir şekilde, himaye edilmiştir. Yâni gelir vergisine tâbi olmayıp işletme vergisine tâbidirler. Işletme vergisi safî ve tahakkuk etmiş bir kazanç üzerinden değii, muhtelif karinelere göre alınan bir vergidir. İnikas tarikiyle istihlâk vergileri gibi fiatlarm yükselmesi suretiyle hayatın pahalılaşmasina, binaenaleyh işçierin durumunun daha da güçleşmesine sebep olabilir. Sonra ayırımı yapamıyacak kadar zayıftır. Bir nevi ruhsat harc1 şeklinde olup nihayet gelir vergisine $0_{0}^{\prime} 8-6$ bir te- 
zayüt teşkil etmektedir. Şu halde vergi sistemimizde sırf emeð̛iyle geçinenlerin çalışma gelirlerini, sermaye gelirlerinden veya sermaye ve çalışmanın memzucu gelirlerden sarih ve esash surette ayrı nisbetlere tâbi tutacak bir değişiklið̆e lüzum vardır. Vergide şahsiyet ve işçiler lehine muafiyetler, indirmeler:

Vergi mevzuatından en mühim bir prensip olan ayırım prensipini böylece izah ettikten sonra işçiler için bu prensip kadar mühim olan asgarî yaşama muafiyeti $=$ l'exemption de minimum d'existence konusuna geçelim : Muafiyet umumiyetle vergide umumiyet kaidesine mugayirdir. Hele hiçbir zaman bir içtimaî sınıf için muafiyet kabul olunamaz. Ancak muayyen şu veya bu verginin muafiyeti vardır. Muafiyet bazen lüzum ifade eder. Hattâ vergi karşısında fertlerin müsavatı için lâzımdır. Fakirler veya ücretten alınan ufak gelirlerin bazı vergilerden mauf olması umumiyet = généralité de I'impôt kaidesine muhalif dẹ̛ildir. Hattâ bu keyfiyet vasıtalı vergilerin fakir sınıf üzerindeki, zengin sınıfa nazaran daha ağır olan yükünün mukabil ivazım teşkil eder. Umumiyetle kabul edildiğine göre, işçilerin ve emeğiyle geçinenlerin ancak kendi ve ailesinin en asgarî şekilde geçinmesine, daha dołrusu idamei mevcudiyet etmesine lâzım gelen meblâł $=$ minimum d'existence vergiden muaftır. Bu da gayet tabiîdir. Çünki bu asgarî miktardan bir santim dahi eksilse hayat, yaşama imkânı kalmaz. Bundan ne vergi alınabilir, ne borç için haciz edilebilir. Bugün bedihi görülen kat'î olarak bütün memleketlerin vergi sistemlerinde kabul edilen bu prensibe dahi evvelce itiraz edenler olmuştur. Vergi umumî bir mükellefiyettir. Ekonomik noktadan vergi istihsalin zarurî masrafları arasına girer. Her fert diğer istihsal masrafları gibi ödemelidir. Politik noktadan umumî intihabat rejiminde bir sinıfın vergiden hariç kalması muvafı değildir denilmiştir. Bunlar arasında Robespierre de vardır. Robespierre asgarî geçim muafiyetini halka bir hakaret, demokrasinin azalması olarak telâkki eder. Tabiî bugün bu nazariyenin sâliki kalmamıştır. Ancak asgarî geçim haddinin tayini çok büyük güçlükler arzeder. Zira bu had, yaşama standardı ile ilgilidir. Her memlekete, her zamana göre değişir. Bazlları bu hadde muayyen bir asgarî konfor için lâzım olan masrafları da ilâve ederler. Bu had, senelik olmak şartiyle Fransa'da 10.000 frank, Ingiltere'de 250 sterling, Almanya'da $1<00$ rayşmark, Italya'da 2000 liret, Amerika Birleşmił devletlerinde bekârlar için 3000 ve evliler için 5000 dolardır. 
Fiatların ve binaenaleyh ihtiyaçların para ile ifadesi zamanla ve bilhassa kâłıt para kıymetinin mühim temevvüçlere duçar olduğu zamanlarda çok değiştiğinden asgarî muafiyet haddini memleketin ihtiyacına göre tesbit etmekle beraber fiatların tahavvülâtına nazaran zaman ile dȩ̛iştirmek de icabeder. Asgarî geçim muafiyet ile asgarî ücret $=$ salaire minima arasında bir nisbet kurmak mümkündür. Filhakika asgarî ücret de asgarî geçim haddinden aşă̛̆ı olamaz. Asgari geçim muafiyeti haddini, muhtelif emeğiyle geçinenler için ayrı ayrı tayin etmek kat'iyyen caiz değildir. Keza bazılan için kabul edip diğerleri hakkında kabul etmemek de hiç doğru deợildir.

Memleketimizde 2395 saylı Kanuna göre âmme hizmeti memurlarında 100 lirayı geçmeyen maaşların 20 lirası, .âmme hizmeti müstahdemlerin de yâlnız 20 lirayı geçmiyen ücretler, iş̧̧ilerde 120 kuruş gündeliğe kadar 80 kuruşu kazanç vergisinden müstesnadir. Gündelik gayri safi kazançları üzerinden teklif edilen işçilerin muafiyetinde Maliye Bakanlığınca tereddüt edilmekte olduŏgu gibi kabul de olunsa bu, gelir miktarına göre değill, yaşa göre bir muafiyettir. Aylıklı işçi ve müstahdemler için muafiyet kabul olunmamıştır. Malûmdur ki kazanç vergisi ile beraber iş̧iler ve emeğiyle geçinenlerden alınan diğer vergilerin asgarî muafiyet hükümleri de ayrı ayrıdır. Ve hepsi bir arada tam bir karışıklık= confusion halindedir. Filhakika âmme hizmeti memur ve hizmetlileri için 150 liraya kadar 30 lirası buhran vergisinden, vergiler çıktıktan sonra 20 liraya düşen maaş ve ücretler muvazene vergisinden muaftır. Işçilerde muvazene vergisi muafiyeti, kazanç vergisi muafiyeti gibi 120 kuruş "gündeliğe kadar seksen kuruştur. Buhran vergisi muafiyeti ise 150 liraya kadar aylık tutarın 30 lirasıdır. Kazanç vergisi muafiyetinden istifade etmiyen aylıklı hususî ücretli işçilerin ve müstahdemlerin buhran ve muvazene vergileri muafiyetleri âmme hizmeti memur ve müstahdemleri gibidir. Gündelik gayri safi kazançları üzerinden teklif edilen işçiler için kazanç ve buhran vergisinden asgarî muafiyet haddi tanımamış ise de muvazene ve hava kuvvetlerine yardım vergilerine tâbi değildirler. Surf muafiyet bakımından bile bu kadar çeşitli hükümlerin ve vaziyetlerin mevcut olması vergi adaleti bakımından ç̧ok büyük adaletsizlikler tevlit eylemiştir. Emeğiyle geçinenlerin bazılarında asgari geçim muafiyeti kabul olunmuş, bazılarında olunmamış, asgarì geçim haddi 
bir tek olmak icabederken yedi nevi olarak kabul oluumuş, her vergide ayrı ayrı muafiyet hükümleri vazolunmuștur.

Sonra ayda 20 lira günde 80 kuruş halihazır şartlarına nazaran asgarî geçim haddine cevap vermekten uzak bulunmakta ve kuru ekmek parasına dahi tekabül etmemektedir. 2000 liradan aşağı gayrı safi iradlı yerlerde ticaret ve san'at icra edenler yanında çălışanlar hizmet erbabı gibi teklif edilmediklerinden asgarî muafiyetten faydalanamamaktadırlar. Yeni gelir vergisi tasarısında bu mahzurlardan birçơ̆u izale edilmektedir. Birleştirilmiş ve umumileştirilmiştir. Ancak asgarî geçim muafiyeti haddi, aile $y u ̈ k u ̈ ~=$ charges de famille muafiyetiyle birleștirilmek istenilmiştir. Bekârlar için günde: 1 lira hesabiyle ayda 26 lira ve senede $31 \iota$ lira

Evli ve çocuksuzlar için günde 1,5 lira hesabiyle ayda 39 lira ve senede 468 lira

Çocuklu evliler için günde 2 lira hesabiyle ayda 52 lira ve senede 624 lira olarak tesbit olunmuştur. Evvelâ asgarî geçim muafiyeti haddi kanaatimizce, hele yeni fiat ve hayat pahalılı̆̆ vaziyetleri gözününde tutulursa hiç kâfi değlldir. Sonra aile yükü $=$ charges de famille muafiyetiyle asgarî geçim muafiyetini birleștirmeł̆e taraftar değiliz. Bu şekilde bu muafiyetlerin hükümleri arzu edildiği kadar genişletemez. Dar kalmăga mahkûm olur. Asgarî geçim muafiyetini matrahtan, aile yükü muafiyetini tarholunan vergiden yapmak muvafik olur, dið̆er memleketlerin çoğunda böyledir. Filhakika bütün medenî memleketlerde emeğiyle geçinẹnler ve iş̧̧ilerin tâbi olduğu vergi sisteminin en karakteristiği de mükelleflerin aile yüklerinin nazarı itibare alınması, her aile ferdi için vergiden bir miktar tanzilâi yapımasının kabul olunmasıdır. Her kazanç erbabına, bu prensip tatbik edilmekle beraber bilhassa emeğiyle geçinenlerde dĭ̛er kazanç erbabına nazaran çok daha fazla miktarda tenzilât yapılmaktadır. Bu nokta üzerinde ssrarla duruyoruz. Zira yeni gelir vergisi tasarısında bu hususta işçilerle tüccar ve sermayedarlar arasinda fark gözetilmemiş olsını büyük bir noksan sayıyoruz. Zira diğer kazanç erbabı için aile fertlerinin miktarı ve kesreti az çok geçim üzerine tesir etmekte ise de emeł̧i ile geçinenlerde, bilhassa işçilerde aile efradının kesreti geçim üzerine yıkıcı bir tesir yapacak kadar ehemmiyet kesbetmektedir. Hemen bütün medenî memleketlerde ve balkan memleketlerinde aile yükü muafiyeti, bilhassa işçiler 
için çok geniş miktarda, muayyen bir miktar çocuk adedinden sonra tam muafiyet verecek surette tatbik olunmaktadur. Aile yïkü muafiyetinden nazara alınacak efrat, nafakası mükellefe vàcip olan kimselerdir. Bunlar muhtaç ve yaşlı usul, rüşt sinnine vasıl olmıyan fürư̆ ve evlâtlıklardır. Fransa'da 1938 senesinde yalınız fürư̆ kabul olunmuştur. Son vaziyete göre Fransa'da 10000 franka kadar vergiden ilk iki çocuk için $\% 20$ ve üçüncüden itibaren her biri için $\% 60$ tenzil olunmaktadır. 10000 franktan yukarı vergilerde bu nisbet $\% 15$ ve 0.45 dir. Şu halde birinci halde üçüncü çocukta, ikinci halde dördüncü çocukta tam muafiyet hasıl olmaktadır. Ayrıca iradî umumî vergisinde de tenzilat yaplur. Ingittere'de birinci çocuk için 60, diğerlerinin beheri için 50, usulden ilki için 50, diğerlerinin beheri için 25 isterling tenzilat yapilhr. Italya'da her aile ferdi için 3000 lireti geçmemek üzere 1/20 tenzilât yapılmaktadır. Almanya'da mükellefin arzusuna göre, ya her şahıs için götürü bir miktarda tenzil olunur veya matrai yekûnundan işçiler ve emeł̆iyle geçinenler için $\%$ : diğer kazanç erbabından $\% 8$ tenzilât yałulır.

Görülüyorki asgarî geçim muafiyeti umumiyetie matrahtan yapuldıktan sonra iş̧̧iler ve emeğiyle geçinenler için çok farkh favör muamelesi tatbiki suretiyle aile yükü masrafları tanzilatı vergiden yapılmaktadır. Bizde de böyle olması lâzımdır. Yani, vergi sistemimizde mevcut olmıyan aile yükü tenzilâtı iş̧̧̧iler için farklı olmak üzere tarhedilen vergilerden indirilmeli, fakat ayrica matrah üzerinden asgarî geçim muafiyeti tatbik olunmalıdır.

İş̧i gelirlerinin vergiye tâbi tutulmasında digger bazı muafiyetlerin de nazarı dikkate alınması lâzımdır. Meselâ; Patron tarafından çok çocuklu iş̧ilere verilen aile allokasyonları, aile yardımlarmın vergi mevzuuna girmediği aym sebeblerle, tasrih olunmalıdır. Tekaüt aidatı, sosyal sigortalar, hayat sigortaları primleri. vergi mevzuuna girmez. Keza iş̧̧i ve müstahdem tarafından işin icrası için yapılan masraflar meselâ yer değiştirme, ev değiştirme, teknik kitaplar tedariki işin icrası için yapılacak fazla yemek masrafları da vergi mevzuu haricinde kalır. Harcurah ve ikamet ve seyyahat yevmiyelerinin bu suretle tamamen muaf tutulmas! lâzımdır. Memieketimizde yol paraları ve zarurî masraflar, bütün kazanç erbabı için kazanç ve buhran vergilerinden müstesna tutulmuş ise de muvazene vergisi yalnız âmme hizmeti memurlarınıs ikamet ve seyyahat yevmiyelerini muaf tutmuştur. Umumî mües- 
seseler için üç buçuk ve on liraya kadar yevmiyeler muaftır. Iş̧̧i ve müstahdemlerin yol paraları muvazene vergisine tâbidir. Keza aile allokasyonları muafiyeti de mütalâa edilmemiștir.

Muhtelif memleketlerde mecburi çalı̧̧ma saatlerinden fazla olarak işçiler ve müstahdemler tarafından yapılan munzam mesai himaye edilmektedir. Memleketin iktisadî kalkınması çok çalışmakla mümkün olacăğndan, munzam mesainin himaye ve teşviki tâbiidir. Bütün medenî memleketler iş kodlarında ve memleketimizde 3008 sayılı Is Kanununda, munzan mesainin farklı ve fazla ücrete tâbi olacăğ kabul olunmuştur. Munzam mesainin memleket iktisadiyatındaki çok mühim ve lüzumlu rolü dolayısiyle vergi noktai nazarından da himayesi icabeder. Iş̧̧inin munzam çalışma dolayısiyle eline geçen paranın ehemmiyetine göre munzam mesaiyi daha çok sevip benimseyeceği tâbiidir. Aynı zamanda bu para mecburi ve normal çalışma şartları haricindeki çalışmanın telâfisidir. Işte bu sebepler dolayısiyle bazı memleketlerde munzam mesai ücretleri vergiden istisna edilmiştir. Fransa'da 2.5.1938 tarihli Decret-loi'nin 39 uncu maddesiyle munzam mesai ücretleri gelir vergisinden tamamiyle istisna edilmiştir. El emeği boşluğu olan memleketimizde bu boşluğu ancak çok çalışmakla doldurabiliriz. Binaenaleyh munzam mesai ücretlerini vergiden muaf tutmamız çok yerinde ve lüzumlu bir tedbir olacaktır.

Iş̧ilerin gayri safi değil, safi gelirlerinin vergiye tàbi olması her tarafta kabul olunan bir prensiptir. Şu haie nazaran tevsik olunan muvazaadan âri borç faizlerinin de matrahdan tenzili icabeder. Diğer memleketlerde bu, böyledir. Bizde sanayî ve ticaret erbabının borçlarına ait faizier matrahdan tenzil olundliğu halde işçiler için bu indirmenin yapilmaması muvafık deģildir.

Isş̧ilerin gelirlerinden alınan vergileri tetkik ederken biraz müterakkiyet $=$ progressivité den de bahsetmek icabeder. Ancak vergi nisbetlerinin müterakki mi, nisbi mi olması meselesi umumî bir meseledir. Ve yalnız işçilerden alınacak vergilere münhasır değildir. Zira ücretler, hele gündelikler müterakkiyetin tamamiyle tatbikine müsait olacak dereceye yükselmezler. Ücretlerin çoğu birinci kademede kalır. Iş̧̧iler için müterakkiyet bahsinde mühim olan cihet şudur: Asgarî muafiyet haddini takibeden ilk hadler, asgarì geçim haddinin üstünde olmakla beraber nisbeten zarurî ihtiyaçlara cevap verirler. Bunun için kısmen matrahtan tenzilleri cihetine gidilir. Netekim Fransa'da 10.000 frank kadar olan gelir, 
tamamen istisna edildikten sonra $10-20$ bin frank arasında olan kısım yarı yarıya $20-40$ bin frank arasinda olan kısim "/4 sayılur. Ingiltere'de ilk vergiye tâbi 250 ingiliz lirası $5 / 9$ nisbetinde matraha girer. Italya'da $2000-2500$ liret arasindaki ücretler, Almanya'da $1200-1800$ rayşmark arasındaki kazançlar ayni suretle tenzilâta tâbidir. Bizde 2395 sayılı kanunla, bu husus, memurlarla işçiler için tatbik edilmek istenilmişse de vergi tekniği noktasından kusurlu olduğu için bazı maaş ve gündeliklerin artmasiyle memur veya iş̧̧inin eline daha az para geçmesi gibi garip bir nelice hâsl olmuştur. Filhakika 120 kuruşa kadar gündeliklerin 80 kuruşu kazanç ve buhran vergilerinden müstesna tutulmuştur. Keza 100 liraya kadar maaşların 20 lirası kazanç vergisinden ve 150) liraya kadar 30 lirası buhran vergisinden müstesnadır. Binaenaleyh maaş 101 lira ve gündelik 121 kuruş oldu mu bütün matrah vergiye tâbi tutulmaktadır. Bu şekilde 120 kuruş alan iş̧̧inin eline 109 kuruş geçtiği halde 130 kuruş alan işçinin eline 105,90 kuruş geçnektedir. Yukarıda arzettiğimiz memleketlerde tatbik edilen usulün mümasili usuller tatbik olunursa bu mahzur şüphesiz kalmıyacaktır.

\section{Tarh usulleri :}

Işçilerin gelirlerinden alınan vergilerin tarh usutleri hakkında da birkaç kelime söyliyelim : Malûndur ki iş̧̧i vergilerinin tarh ve. tahsili umumiyetle mahallinde tevkif $=$ stoppage à la source usuliyle olur. Yani mükellefin vergisini hesap edip veren bir üçüncü şahıstır. Iç̧silerde işveren, patrondur. Bu usul hazine için bir kolaylik ve garanti temin etmekle beraber mükellef için, vergisinin bir başkası tarafından yanlıs hesap edilmesi ve itiraz formaliteleri dolayısiyle mahzurları haizdir. Bizde hizmet erbabı, tarh ve tahsil bakımından ikiye ayrılmıştır. Âmme hizmeti memur ve müstahdemleriyle sair müstahdemler ve işçilerin hakikì maaşı veya ücretlerinden vergi tediye sırasında kesilir. Yâni stopaj usulü caridir. Amme hizmeti memur ve müstahdemleriyle Bankalar ve sermayesinin yarısı Devlet tarafından verilen müesseseler için aylık bordro tanzim edilmez. Verginin tediyeyi müteakip bir haftada yatırlması lâzımdır. Sair müstahdem ve işçiler. için aylık bordro tanzim olunur. Ertesi ayın 20 nci günü akşamına kadar bu bordrolar teslim ve ayni günde vergi tediye olunur.

Íkinci kategori, gayrısafi iradı iki bin lirayı geçmiyen yerlerde ticaret ve sanayi icra edenlerin yanında çalışan iş̧̧ilerdir ki 
mahsus komisyonlarca götürü = forfaitaire bir miktar olarak tâyin edilen gündelik gayrısafi kazançlarının muayyen bir kısmını vergi olarak seyyar mükellefler gibi verirler. Bu ikilik gerek tarh ve tảhsil, gerek nispet, gerek muafiyet bakımından adaletsizlikler hâsıl etmektedir. Bunlara asgarî muafiyet kabul edilmemesi dolayısiyle çıraklık müessesesinin sönmesi tehlikesi hâsıl olmuştur. Keza vergi kaçakçılığına daha müsait olması itibariyle de büyük işyerlerinden küçük işyerlerine müteveccih bir iş de ğiştirmeye de sebep olmaktadır. Yeni gelir vergisi tasarssiyle bu ikilik ortadan kaldırılmamıs, şüphesiz daha ziyade bu ikilið̧in devam ettirilmesinde teknik mülâhazalar hâkim olmuştur. Iş̧̧ilerin vergi mevzuatı karşısındaki durumunu bu şekilde kısaca arzetmiş olduk. Netice itibariyle diyebiliriz ki bu konuda her şeyin yeniden yapilması icab etmekle beraber bir prensip olarak mesele ortaya atılmış bulunmaktadır. En doğru, memleketimizin bünyesine en uygun, en âdil ve işçilerimizin yüzünü güldürecek, yaşama seviyesini yükseltecek bir tarzda halledileceğinden şüphe etmiyoruz. 